\title{
ДЕЛО «ФУРМАН ПРОТИВ ДЖОРДЖИИ» И ЕГО ВЛИЯНИЕ НА РАЗВИТИЕ ИНСТИТУТА СМЕРТНОЙ КАЗНИ В США
}

\section{Барышев E.O.}

Аннотация: Предметом исследования является рассмотрение правовых аспектов дел «Фурман против Джорджии», «Грегг против Джорджии» и других значимых кейсов, повлиявиих на развитие института смертной казни в Соединенных Штатах Америки во второй половине ХХ в. Автор подробно рассматривает фабулу дела «Фурман против Джорджии», останавливается на сочиальных и правовых предпосылках введения моратория на смертную казнь в 1972 г. и его отмены в 1976 г. Особое внимание уделяется анализу позищий судей Верховного Суда США и постфурмановским тенденциям. Главными методами исследования выступают формально-юридический и сравнительно-правовой. Работа основывается на анализе ключевых дел Верховного Суда США. Значительное внимание уделяется рассмотрению эволющии вопроса с помощью исторического метода. Основными выводами проведенного исследования являются следующие положения: 1) ведение временного моратория на смертную казнь в США - необходимый этап правой эволюиии; 2) пауза была необходима для реформирования уголовно-процессуального законодательства, решения острых сочиально-юридических проблем, так или иначе связанных со смертной казнью. Новизна исследования заключается в том, что в российской литературе ранее комплексно не изучался вопрос введения и последующей отмены моратория на смертную казнь в США. Автор заключает, что в будущем маловероятна постановка вопроса о конституционности смертной казни в США, поскольку во второй половине ХХ в. была намечена тендениия совершенствования правовой прочедуры. Метод, методология исследования. В проиессе исследования применялись общефилософские методы (диалектика, системный метод, анализ, синтез, аналогия, дедукиия, наблюдение, моделирование), правовые методы (формально-логический), а также методы, используемые в конкретно-социологических исследованиях (статистические, экспертные оченки и др.). Дело Грегга стало закономерным продолжением дела Фурмана. Смертная казнь развивается по своему пути независимо от желаний и стремлений Судей Верховного Суда США, являясь значимым общественно-политическим феноменом и определенным паттерном в сознании американского общества. Судьи Верховного Суда наравне с гражданами являются участниками единого исторического прочесса. Рассмотренные посфурмановские тенденции выравнивают, корректируют применение «жестоко и необычного наказания». Можно предположить, что вопрос гуманизации и совершенства процедуры будет еще актуален в течение долгого времени. 
Ключевые слова: Смертная казнь, демократия, права, свобода, мораторий, нарушение, санкиия, Суд, защчита, дело.

Соединенные Штаты Америки - одно из немногих государств, применяющих в настоящее время смертную казнь в качестве высшей меры уголовного наказания. Смертная казнь в США имеет глубокие культурные и социологические основания, связанные с ходом американской истории, а также особенностями правовой системы. Как иногда справедливо отмечают, «маяк демократии, хранитель всемирных прав и свобод людей санкционирует лишение жизни в пределах своих границ, в то время как многие страны уже давно отказались от этой практики» [1]. В Северной Америке история смертной казни насчитывает четыре столетия: она существует с момента основания англо-саксонских колоний. Имеется достаточно оснований полагать, что современное состояние смертной казни сформировано делом «Фурман против Джорджии» (1972 г.) . Решением по данному делу на всей территории США был установлен мораторий на смертную казнь, продлившийся, однако, всего четыре года. Дело Фурмана является ключевым в правовой истории смертной казни в США, которую в связи с этим принято делить на два периода: «дофурмановская» и «постфурмановская» эры.

Уильям Генри Фурман, малообеспеченный и неоднократно судимый за незначительные правонарушения афроамериканец, утром 11 августа 1967 г. проник в дом в городе Саванна (округ Чатем, штат Джорджия) с целью ограбления. Фурман был вооружен пистолетом, из которого впоследствии был убит хозяина дома. Сразу после содеянного Фурман скрылся, однако был вскоре задержан в своем доме. На допросе Уильян Фурман признался, что хозяин дома обнаружил его на кухне и попытался обезвредить, поэтому Фурман выстрелил и затем покинул место преступления. Однако позднее, во время судебного разбирательства, Уильям Фурман утверждал, что не намеревался убивать хозяина дома и что выстрел был чистой случайностью.
По словам Фурмана, услышав шаги за дверью, он попытался скрыться, но споткнулся о провод на полу, и именно в этот момент произошел самопроизвольный выстрел.

Перед присяжными заседателями окружного суда Чатема встала сложная задача: помимо решения о виновности подсудимого и квалификации противоправного деяния им предстояло выбрать также соответствующую меру наказания. При совершении умышленного убийства в соответствии с законодательством Джорджии санкциями являются либо пожизненное заключение, либо смертная казнь на электрическом стуле. После полутора часов обсуждения заседатели вменили Фурману косвенный умысел и признали его виновным в убийстве в ходе вооруженного ограбления, приговорив к смертной казни. Статистика по штату Джорджия в 1970-1980 гг. показывает, что в подобных случаях афроамериканцев чаще всего лишали жизни. Таким образом, расовая принадлежность сама по себе являлась аргументом для того, чтобы приговорить Фурмана к смертной казни.

Государственный адвокат Фурмана, Б. Кларенс Мэйфилд, проанализировал материалы дела и нашел серьезные нарушения материального и процессуального характера. Адвокат отметил, что игнорировались право на должную правовую процедуру (due process clause) и принцип равенства всех граждан перед законом (equal protection clause), закрепленные Пятой и Четырнадцатой поправками к Конституции США соответственно. Наиболее существенным нарушением являлось то, что в процессе задержания У. Фурману не было разъяснено так называемое Правило Миранды (Miranda warning). Оно сформулировано известной максимой: «Вы имеете право хранить молчание. Всё, что вы скажете, может и будет использовано против вас в суде. Ваш адвокат может присутствовать при допросе. Если вы не можете оплатить услуги адвоката, он будет 
предоставлен вам государством. Вы понимаете свои права?». Наконец, Мэйфилд отметил, что смертная казнь нарушает Восьмую поправку к Конституции США, являясь жестоким и необычным наказанием.

Вначале Б. Кларенс Мэйфилд попытался обжаловать решение в Верховном Суде Джорджии, где в повторном рассмотрении дела ему отказали. Впоследствии адвокат обратился в Верховный Суд США, который принял дело к рассмотрению, объединив его с двумя делами об изнасиловании: «Бранч против Техаса» и «Джексон против Джорджии», где виновные также были приговоренными к смертной казни афроамериканцами. Судебное разбирательство началось 17 января 1972 г.

Верховный Суд Соединенных Штатов Америки в своих предыдущих решениях не раз касался вопроса смертной казни. Так, в рамках Восьмой Поправки к Конституции США (запрет жестоких и необычных наказаний) он признал конституционность расстрела и применения казни на электрическом стуле в деле «Вилкерсон против Уты» (1879 г.) и в «Деле Кеммлера» (1890 г.) соответственно.

К началу 1970-х гг. в Верховный Суд США в порядке обжалования поступило около двух тысяч дел, связанных со смертной казнью, было понятно, что возникла потребность решения вопроса ее применения в целом в рамках конституционного судопроизводства. В деле «МакГаута против Калифорнии» (1971 г.) Суд признал конституционным вынесение смертного приговора без предварительных судейских установок в рамках единой правовой процедуры. Именно после судейского раскола в этом деле (пятеро судей против четверых при голосовании) общество стало неумолимо выступать против санкционированного государством убийства.

В обществе господствовала идея представления Верховного Суда как двигателя прогресса и социальных изменений, хотя не все теоретики права и судьи были готовы с этим согласиться. Несколько позднее в США появилась так называемая критическая расовая теория (racial law theory), связанная с рассмотрением черного населения как заведомо слабой стороны в юридических отношениях. Судьи Верховного Суда США понимали, что общественное мнение крайне нестабильно, поэтому значительное сокращение смертных приговоров возможно было только путем принятия конкретного судебного решения прецедентного характера. Только благодаря указанному стечению обстоятельств Мэйфилду удалось довести дело до конституционного надзора. Выбор Верховного Суда в пользу дела Фурмана как модельного определила его особая подоплека, связанная с расовой дискриминацией.

Интересы Уильяма Генри Фурмана, а также приговоренных к смертной казни в смежных делах в Верховном Суде защищал Фонд Юридической Защиты и Образования (Legal Defense and Education Fund; LDF), куда сразу же был принят Б. Мэйфилд. Фонд был создан в 1940-х гг. как структурное подразделение Национальной ассоциации содействия прогрессу цветного населения (National Association for the Advancement of Colored People; NAACP). Фонд Юридической Защиты и Образования - одна из крупнейших американских правозащитных организаций, одержавшая ряд побед в Верховном Суде США в борьбе за инклюзивность образования; добившаяся запрета на расовую сегрегацию в общественных местах; признания пассивного избирательного права для чернокожего населения и снятия других правовых ограничений.

В 1960 г. Фонд поставил своей основной задачей добиться отмены смертной казни. Организация заинтересовалась этим вопросом преимущественно исходя из защиты прав афроамериканцев: LDF, безусловно, находил расовую дискриминацию в вынесенных смертных приговорах.

На самом судебном заседании сторону защиты представлял член Фонда, профессор юридического факультета Стэндфордского Университета (Leland Stanford Junior University; Stanford University), Энтони Г. Амстердам. Его аргументы о неконституционности решения по делу Фурмана можно разделить на две группы: 
1) доводы относительно нарушения права на должную правовую процедуру (например, присяжные заседатели не получили должных инструкций и поэтому вынесли решение произвольно и необоснованно)

2) аргументы по существу, т.е. доказывающие неконституционность смертной казни независимо способа ее применения (в рамках Восьмой поправки).

Изначально Верховный Суд США сконцентрировал свое внимание на ключевом вопросе объединенного дела: является ли смертная казнь (в этих случаях) жестоким и необычным видом наказания, нарушающим Восьмую и Четырнадцатую поправки к Конституции? Однако впоследствии стало ясно, что правовая борьба выйдет за рамки этих трех дел. Сторона защиты в конечном счете выступала за отмену смертной казни в принципе. Сторона обвинения доказывала, что смертная казнь существует в США с момента основания, поэтому нет причин ее отменять. Верховному Суду США предстояло решить одновременно два вопроса: 1) о допустимости смертной казни в рамках действовавщего на тот момент процессуального законодательства и 2) о ее конституичионности как таковой в качестве высшей меры уголовного наказания.

Как известно, в итоге Верховный Суд США установил мораторий на смертную казнь решением от 29 июня 1972 г. Пятеро судей из девяти признали ее неконституционным видом наказания. Они ссылались на дела «Вимс против Соединенных штатов» (1910 г.), где подчеркивался запрет на жестокие и необычные наказания, установленный Восьмой поправкой; «Троп против Дуллеса» (1958 г.), в котором было решено, что поправки к Конституции должны обозначать «развивающиеся общественные стандарты благоразумия».

Как и в МакГауты, единая позиция суда не была сформирована. Важно подчеркнуть, что отсутствовало общее мнение большинства (majority opinion) и было написано четыре особых мнения (dissenting opinions). Это, безусловно, говорит об отсутствии единой и объективной точки зрения по вопросу конституционности смертной казни.

На тот момент в составе Верховного Суда США находилось пятеро судей эпохи Эрла Уоррена (председателя Верховного Суда США в 1953-1969 гг.), а именно Уильям А. Брэннан, Тергуд Маршалл, Уильям О. Дуглас, Поттер Стюарт, Байрон Р. Уайт. Все пятеро проголосовали за отмену смертной казни. Таким образом, их мнения являются совпадающими (concurring opinions)

Брэннан и Маршалл опирались на аргументацию по существу в рамках Восьмой поправки, считая, что смертная казнь неконституционна сама по себе. По мнению Уильяма А. Брэннана, смертная казнь - это сознательное причинение физических и душевных страданий, умаляющее человеческое достоинство. Он остановился на проблеме произвольности вынесения приговоров, их «лотерейности»и потери былой превентивной функции.

Вторя Бреннану, Тергуд Маршалл утверждал, что Верховный Суд обязан запретить смертную казнь в связи со сменой эпохи. По его мнению, в современном мире она не прошла «тест на гуманность». Вся аргументация Маршалла в основном сводилась к тому, что мщение и возмездие не могут являться целями наказания. Примечательно, что Т. Маршалл являлся одним из основателей Фонда Юридической Зашчиты и Образования.

Оставшиеся трое судей поднимали вопрос нарушения должной правовой процедуры. Уильям О. Дуглас считал, что смертная казнь неконституционна в силу нарушения принципа равенства всех перед законом и отсутствия четких стандартов правосудия. Она необычна, когда становится инструментом расовой, религиозной, социальной, классовой дискриминации или когда применяется в результате процедуры, создающей почву для таких предрассудков.

Исторической стала фраза Поттера Стюарта, что «внезапный удар молнией так же жесток и необычен, как и смертный приговор» («These death sentences are cruel and unusual in 
the same way that being struck by lightning is cruel and unusual»). В свою очередь судья остановился на непоследовательности и произвольности вынесения смертных приговоров. Казнь неконституционна в силу своей бессистемности, а не жестокости и элементов дискриминации.

Байрон Р. Уайт единственный из пятерки Уоррена являлся сторонником смертной казни. Он хотел как можно скорее преодолеть случайности в решениях судей и присяжных заседателей и тем самым достигнуть стабильности. Уайт выступал за последующее возвращение смертной казни как конституционного вида наказания после преодоления процессуальных и правоприменительных проблем. По его мнению, конечной целью решения по делу Фурмана должно быть, наоборот, увеличение числа приговоров.

За сохранение казни выступили: сам председатель Верховного Суда Уоррен. Бергер, Льюис Ф. Пауэлл, Гарри Блэкман, У. Ренквист. Уоррен И. Бергер начал, во-первых, с того, что «нерегулярность казней не делает их необычными»; Конституция сама по себе не запрещает применение смертной казни. Во-вторых, он указал, что Суд не имел право вмешиваться в компетенцию Конгресса. У. Бергер отметил: более двух третей штатов сохранили смертную казнь. Говоря о бессистемности приговоров, он заключил: судьба распоряжается так, что жизни зависят от случайных обстоятельств, никак не продиктованных законом.

Льюис Ф. Пауэлл согласился с Бергером. По его мнению, Суд преувеличил свое значение в правовой системе. Пауэлл считал, что в подобных случаях Верховный Суд должны контролировать общие правовые принципы. Таковыми являются: «стоять на решенном» (stare decisis), федерализм, разделение властей (separation of powers), судебная сдержанность (judicial restraint), в соответствии с которым судьи должны стараться сводить к возможному минимуму рассмотрение вопросов о признании закона неконституционным. Поднимая вопросы расовой дискриминации, судья напомнил о социальных предпосылках правонарушений. Неимущие слои населения находятся в уязвимом положении и поэтому преступают закон.

Гарри А. Блэкман не видел никаких предпосылок для отмены смертной казни. По его словам, такого рода вопрос - компетенция законодательной ветви власти. Блэкман заключил, что судьи не имели права вмешиваться и навязывать обществу свои личные убеждения.

Наконец, Уильям Х. Ренквист еще раз подчеркнул, что судьи преувеличили свои возможности, не оценив последствия решения в соответствии с принципом судебной сдержанности. Они нарушили закрепленный Отцамиоснователями принцип сдержек и противовесов (checks and balances). Также Ренквист обратил особое внимание на психологический аспект, а именно значительный объем судейской власти, позволивший претворить в жизнь судьям свои убеждения. Они фактически вышли за пределы требуемой правовой защиты.

Не будет преувеличением сказать, что дело Фурмана сфокусировало общественное внимание на смертной казни как никогда ранее. Впервые в истории США Верховный Суд принимал решение о конституционности смертной казни как таковой, а не о правомерности ее применения в конкретном случае. Отмена смертной казни стала важным шагом на пути к стандартизации уголовного процесса, поскольку многие суды злоупотребляли своими полномочиями в этой части. Наконец, решение по делу Фурман против Джорджии способствовало снижению конфликтов на национальной почве, оно в определенной мере сглаживало проявления расизма. В обществе стало распространяться убеждение, что Америка, как и Великобритания, никогда больше не вернется к практике применения смертной казни. Но вскоре стало очевидно, что это не точка, а лишь запятая в правовой дискуссии - решение было локальной победой для тех, кто стремился упразднить институт смертной казни. Уоррен И. Бергер заявил: «в этой стране нет и не может быть равноценной замены сметной казни».

Двое судей из пяти (Бреннан и Маршалл) проголосовали за отмену казни из личных 
убеждений, остальные (Дуглас, Стюарт, Уайт) - исходя из потребностей времени. Таким образом, Суд был в шаге от сохранения казни. Перевес оказался незначительным. Введение моратория во многом является личной заслугой Б. Мэйфилда, Энтони Амстердама и юристов LDF, сумевших сконцентрировать внимание судей эпохи Э. Уоррена как на проблемах по существу (Восьмая поправка), так и на процессуальных нарушениях (Четырнадцатая поправка).

Дело Фурмана, по сути, поставило перед американским народом вопрос: хотят ли они в дальнейтем видеть продолжение правовой истории смертной казни или оставить все, как решил Верховный Суд в 1972 г.. В итоге «Фурман против Джорджии» вместо того, чтобы снизить, только обострил противоречия в обществе: противники смертной казни так и не смогли окончательно убедить общество в своей правоте. Все свелось к тому, что в деле «Грегг против Джорджии» (1976 г.) Верховный Суд США, не связанный своими правовыми позициями, восстановил смертную казнь. Решением было почти единогласным: семеро судей проголосовало за возвращение этого вида наказания.

Итак, после вынесения решения по делу Фурмана в Верховный Суд США продолжали поступать дела, где остро поднималась проблема применения смертной казни. В период с 1972 по 1976 гг. суды штатов приговорили к смертной казни 460 человек. Этого было достаточно для того, чтобы Суд выбрал наиболее «целенаправленные и неизбежно показательные» дела для рассмотрения.

Наконец, 2 июля 1976 г., Верховный Суд США выделил пять дел об убийстве: по одному из Джоджии, Флориды, Техаса, Северной Каролины и Луизианы. В указанных штатах были представлены разные вариации того, что впоследствии теоретики уголовного права назвали постфурмановским уголовным законодательством. Суд поставил задачу разом решить назревший вопрос: пересмотреть изменения 8 правовых системах штатов. Кейсы были объединены под общим названием «Грегг против
Джорджии». За общее дело взялись Тони Амстердам и юристы LDF. Главным сторонником отмены моратория был Роберт Борк, на тот момент и.о. Генерального прокурора США, посвятивший карьеру защите конституционности смертной казни.

Проигрыш Амстердама в этом деле был предопределен: адвокат был скован делом Фурмана, а именно нарушенными правовыми процедурами. К 1976 г. штаты реформировали процессуальное право, устранив выявленные Мэйфилдом и Амстердамом нарушения, поэтому в ходе судебного разбирательства стороне защиты больше не на что было ссылаться.

Верховный Суд США заключил, что смертная казнь при любых обстоятельствах больше не является жестоким и необычным наказанием видом наказания, нарушающим Восьмую и Четырнадцатую поправки к Конституции США. Также было отмечено, что она допустима только за тяжкие преступления, такие как умышленное убийство. Использование смертной казни оправданно в случаях, где соблюдена должная правовая процедура; приняты все меры предосторожности; правовые нормы применены по справедливости. Заключив, что смертная казнь не нарушает Конституцию, Судьи обратились к изентральному вопросу дискуссии: дают ли новые процедуры вынесения приговора судьей или присяжными возможность ограничить или снизить риск возможного произвола и непостоянства в судебных решениях?.

Верховный Суд США пересмотрел законодательство Северной Каролины, Луизианы, Джорджии, Флориды и Техаса. Он признал конституционным только статуты последних трех штатов, исправивших и дополнивших положения о процедуре принятия и осуществления смертного приговора. Процесс судопроизводства они поделили на две независимые части: судебную, где квалифицировалось деяние, и стадию вынесения приговора присяжными заседателями. Выделялся исчерпывающий перечень составов, за которые могла быть наложена смертная казнь. 
В решении по делу «Грегг против Джорджии» судей принято делить на три части в соответствии с их итоговыми позициями по предмету разбирательства. Первая группа, состоявшая из судей Бреннана и Маршалла, придерживалась тезисов, сформулированных в деле Фурмана (смертная казнь неконституционна независимо от процедуры; она противоречит Восьмой поправке). Соответственно, они говорили о противозаконности всех пяти статутов. Вторая группа судей (Ренквист, Уайт, Бергер и Блэкмун) посчитала, что изменений законодательства штатов достаточно для возвращения смертной казни в каждом из них.

Дело решило так называемое «трио Стюарт-Пауэлл-Стивенс», которое нашло противоречащими Конституции только законодательство Луизианы и Северной Каролины [2]. Было отмечено, что, несмотря на различия в правовых моделях, статуты Джорджии, Флориды и Техаса в достаточной мере сузили возможность применения смертной казни и оставили возможность замены на другое наказание - лишение свободы. С другой стороны, Луизиана и Северная Каролина нарушили принцип верховенства права (rule of law), не оставив возможности для замены смертной казни альтернативным наказанием. Их законы не соответствовали основному выводу Верховного Суда: смертная казнь стоит обособленно от других видов наказания не из-за степени (смертная казнь - выстая мера), а из-за самой своей сущности, применимости.

Впоследствии Верховный Суд США еще не раз возвращался (и будет возвращаться) к вопросу смертной казни. Однако здесь важно подчеркнуть, что в постфурмановскую эру не ставится вопрос о конституционности смертной казни как таковой. На данном этапе развития Америки онтологический статус смертной казни не обсуждается, возможность ее осуществления априорна, она является исторической и культурной данностью. Уголовная система идет по демократическому пути - казнь адаптируется под гуманистические идеалы Восьмой поправки и совершенствуется в процедурном отношении в рамках Четырнадцатой.

Например, решением по делу «Кукер против Джорджии» (1977 г.) Верховный Суд запретил смертную казнь за изнасилование. Он заключил, что наказание есть чрезмерное и неконституционное если оно:

1) не соответствует целям наказания и является лишь ненужным и неоправданным причинением физической боли и страданий;

2) не соответствует тяжести преступления. Таковым и является лишение жизни за изнасилование.

Заданное направление совершенствования института смертной казни нашло развитие в деле Кеннеди против Луизианы (2008 г.), где было сформулировано следующее правило: никакой смертной казни в преступлениях, где жертва не была лишена жизни.

Следующим направлением является установление минимального допустимого возраста, с которого можно приговаривать к смертной казни. Такая проблема была подняла в кейсе «Томсон против Оклахомы» (1988 г.). По мнению Суда, Восьмая поправка к Конституции США предполагает особую осторожность в рассмотрении преступлений, за которые возможно вынесение смертного приговора. Отсюда запрещалось казнить лиц, которым в момент совершения преступления было менее пятнадцати лет. На данный момент это правило применяется по отношению к лицам моложе 18 лет - «Рупер против Симмонса» (2005 г.).

Решением по делу «Ринг против Аризоны» (2002 г.) была признана неконституционной возможность присяжных заседателей основываться на найденных судом отягчающих обстоятельствах, достаточных для наложения смертной казни. Верховный Суд США указал, что, поскольку указанные в деле отягчающие обстоятельства фигурируют как «функциональные эквиваленты составной части более серьезного преступления», Шестая поправка к Конституции США требует их нахождения судом присяжных. 
Наконец, кейсы «Гласс против Луизианы» (1985 г.) и «Бэйз против Рииса» (2008 г.) еще раз подтвердили соответственно в первом случае конституционность смертной казни на электрическом стуле, во втором - смертельной инъекции.

Таким образом, ординарный судебный приговор одного из окружных судов штата Джорджия заставил полностью пересмотреть и заново переосмыслить правовую историю смертной казни в США. Стоит также отметить, что правовая полемика выходила далеко за рамки вопросов конституционности рассматриваемого вида наказания. Дело Фурмана напрямую затронуло многие острые проблемы американского общества, такие как социальное неравенство и расовая дискриминация, несовершенство правовой процедуры, неэффективность системы уголовных наказаний, злоупотребление судебной властью на местах, и, наконец, дисбаланс в системе сдержек и противовесов.

Рассмотрение такого сравнительно узкого периода позволяет, однако, утверждать, что на данный момент смертная казнь для Соединенных Штатов Америки есть наиболее общественно приемлемый вид наказания за самые тяжкие преступления. Дело Фурмана стало своего рода «опорой» для дальнейшей стабильности в развитии данного института; являлось предпосылкой для реформирования и унификации на конституционной основе законодательства штатов.

Дело Грегга стало закономерным продолжением дела Фурмана. Смертная казнь развивается по своему пути независимо от желаний и стремлений Судей Верховного Суда США, являясь значимым общественно-политическим феноменом и определенным паттерном в сознании американского общества. Судьи Верховного Суда наравне с гражданами являются участниками единого исторического процесса. Рассмотренные посфурмановские тенденции выравнивают, корректируют применение «жестоко и необычного наказания». Можно предположить, что вопрос гуманизации и совершенства процедуры будет еще актуален в течение долгого времени.

\section{Библиография:}

1. Насонов С.А., Максимова Т.Ю. Уголовно-процессуальные гарантии права обвиняемого не свидетельствовать против себя самого: анализ проблем судебной практики при рассмотрении дел в общем порядке и в суде присяжных // Право и политика. - 2015. - 11. - C. 1618 - 1622. DOI: 10.7256/1811-9018.2015.11.16648.

2. Кабанов П.А. Общественные обсуждения вопросов противодействия коррупции как форма взаимодействия институтов гражданского общества с органами публичной власти при осуществлении общественного контроля // Право и политика. - 2014. - 10. - С. 1515 - 1524. DOI: 10.7256/1811-9018.2014.10.12998.

\section{References (transliterated):}

1. Nasonov S.A., Maksimova T.Yu. Ugolovno-protsessual'nye garantii prava obvinyaemogo ne svidetel'stvovat' protiv sebya samogo: analiz problem sudebnoi praktiki pri rassmotrenii del $\mathrm{v}$ obshchem poryadke i v sude prisyazhnykh // Pravo i politika. - 2015. - 11. - C. 1618 - 1622. DOI: 10.7256/1811-9018.2015.11.16648.

2. Kabanov P.A. Obshchestvennye obsuzhdeniya voprosov protivodeistviya korruptsii kak forma vzaimodeistviya institutov grazhdanskogo obshchestva s organami publichnoi vlasti pri osushchestvlenii obshchestvennogo kontrolya // Pravo i politika. - 2014. - 10. - C. 1515 - 1524. DOI: 10.7256/1811-9018.2014.10.12998. 